\title{
22 \\ Future Water: Improving \\ Planning, Markets, Enforcement and Learning
}

\author{
Cameron Holley
}

\section{Introduction}

Water is indispensable to our life, our economy, our food security and our environment. ${ }^{2}$ Ensuring its protection and sustainable use requires effective and efficient law and policy. Over the last 120 years, our water laws have been on a prolonged reform journey. Spurred by Australia's water-scarce environment and ongoing overallocation challenges, ${ }^{3}$ Australia's water law system has progressed from common law rights, to state regulation, to intergovernmental action under the Council of Australian Governments (COAG) led National Competition Policy reforms and the National Water Initiative (NWI). The latter agreement, which embraced statutory-based collaborative water planning, cap and

\footnotetext{
1 Associate Professor, UNSW Faculty of Law. This research was funded by an Australian Research Council Discovery Early Career Researcher Award (DE140101216) and an Australian Research Council Discovery Project (DP170100281). I am gratefully for the research assistance of Genevieve Wilks, Antonia Ross and Bonnie Perris, and the excellent suggestions made by Darren Sinclair, Ron Levy and the anonymous reviewer of this chapter.

2 UN Sustainable Development Goals, Goal 6, www.un.org/sustainabledevelopment/water-andsanitation.

3 National Water Commission (NWC), Sustainable Levels of Extraction: National Water Commission Position (NWC, 2010).
} 
trade markets, regulation and accounting, monitoring and review, has demarcated Australia as a leading laboratory of water governance. ${ }^{4}$ Even so, after such a long reform journey, fatigue and apathy are increasingly palpable in water policy. ${ }^{5}$ Notwithstanding recent emphasis on northern water resource development, ${ }^{6}$ this equivocation about continued national reforms is jeopardising Australia's long-term water sustainability. ${ }^{7}$

This chapter argues that entrenching and extending national reforms is vital to Australia's future water security. It argues for four key broad reforms. The context and justification for each reform is given by briefly evaluating the performance of NWI planning, markets, regulation and monitoring. The discussion focuses particularly on non-urban water management. This is because agriculture is the largest consumer of Australia's water, making it the area where some of the biggest gains can be made in securing sustainable water management. ${ }^{8}$

\section{Four Fundamental Water Law and Policy Reforms}

\section{A. Prioritise integration and engagement in water planning}

Australia's rivers and aquifers have different local ecologies and are used by many different agricultural communities. Collaborative water plans are the core mechanism for incorporating and managing these diverse contexts and users. While there has been substantial experimentation in

\footnotetext{
4 Lee Godden and Anita Foerster 'Introduction: Institutional Transitions and Water Law Governance' (2011) 22(2/3) The Journal of Water Law 53-57.

5 Cameron Holley and Darren Sinclair 'Rethinking Australian Water Governance: Successes, Challenges and Future Directions' (2016) 33(4) Environmental and Planning Law Journal 275; National Water Commission (NWC), Australia's Water Blueprint: National Reform Assessment 2014 (NWC 2014); Wentworth Group of Concerned Scientists, Blueprint for a Healthy Environment and a Productive Economy (Wentworth Group, 2014).

6 Australian Government, Our North Our Future: White Paper on Developing Northern Australia (2015), northernaustralia.gov.au/files/files/NAWP-FullReport.pdf.

7 NWC, above n 5, 4; Holley and Sinclair, above n 5. See also Productivity Commission (PC), Inquiry into Progress with the Reform of Australia's Water Resources Sector (PC, April 2017), www.pc.gov. au/inquiries/current/water-reform.

8 In a paper of this size, the analysis is inevitably selective in its coverage. It does not cover for example, the Water Act 2007 (Cth) and the Basin Plan 2012 (Cth) in detail. Australian Bureau of Statistics (ABS), Water Account Australia 2012-13 (ABS, 2014); Wentworth Group, above n 5.
} 
water planning across states and territories, ${ }^{9}$ most plans set environmental outcomes, rules for the allocation and trading of water for consumption, and monitoring and reporting requirements. Despite a slow start, there have been noted improvements in the quality and extent of planning across Australia, with some 170 finalised water plans now managing over 80 per cent of Australia's water use. ${ }^{10}$ Despite this progress, water plans continue to suffer from fragmented coverage of uses and a history of poor community engagement.

One of the most prominent examples of fragmentation is the water use of the mineral and petroleum sectors. Recognised as facing 'special circumstances' (e.g. short durations, isolation and difficulties accounting for water extraction), mineral and petroleum developments like coal seam gas were to be addressed outside of the NWI and its plans. ${ }^{11}$ However, these non-NWI regimes have not achieved the level of integration necessary to attend to the interdependencies between these developments and their impacts on water, ${ }^{12}$ not least reduced water availability and altered flows. Significant public concern about these failures ${ }^{13}$ led to a recent patchwork of federal and state reforms (e.g. the Commonwealth's water trigger, bioregional assessments and NSW's Aquifer Interference Policy). However, most of these remain ad hoc or partial, with industries' water use not always well integrated with broader regional water planning processes, and various states continuing to allow industries to sit outside of NWI water plans (e.g. Queensland). ${ }^{14}$

In terms of community engagement, there are many instrumental reasons why community consultation in planning is pursued, including encouraging trust and buy-in, ${ }^{15}$ and developing effective responses to local

9 Poh-Ling Tan, Kathleen Bowmer and John Mackenzie, 'Deliberative Tools for Meeting the Challenges of Water Planning in Australia' (2012) 474 Journal of Hydrology 2; NWC above n 5, 26.

10 National Water Commission (NWC), The National Water Planning Report Card 2013 (NWC, 2013); NWC, above n 5, 26, 351.

11 NWI 2004, cl 34.

12 Karen Hussey, Jamie Pittock and Stephen Dovers, 'Justifying, Extending and Applying 'Nexus' Thinking in the Quest for Sustainable Development' in J Pittock, K Hussey and S Dovers (eds), Climate, Energy and Water (CUP, 2015); NWC above n 5.

13 National Water Commission, 'Coal Seam Gas and Water Position Statement' (NWC, 2012); National Water Commission (NWC), Water for Mining and Unconventional Gas under the National Water Initiative (NWC, 2014) (hereinafter NWC, Water for Mining).

14 NWC, Water for Mining, above n 13, 10; John Williams, Tim Stubbs and Ann Milligan, An Analysis of Coal Seam Gas Production and NRM in Australia (JWSS, 2012).

15 Tom Tyler, Readings in Procedural Justice (Ashgate, 2005). 
problems (e.g. water cutbacks). ${ }^{16}$ However, government designed planning processes have tended to focus on traditional, quick and easy consultation methods (e.g. community meetings or panels), leading to Indigenous and many other interests (e.g. environmental and local farmers) being poorly engaged. ${ }^{17}$ While there are signs of improving consultation in more recent plans, ${ }^{18}$ these advances were arguably slow in coming and have produced profound legitimacy shortfalls and mistrust across affected communities. ${ }^{19}$ As a recent survey revealed, the majority of respondents disagreed that their views about the Basin Plan $(58$ per cent, $\mathrm{n} 4,719)$ and coal seam gas ( 65 per cent, $n$ 1,272) would be listened to. ${ }^{20}$

To successfully resolve the above shortcomings, planning processes must prioritise integration and commitments to deeper stakeholder engagement. This will require new obligations to identify all beneficiaries and interests affected by planning up front (so as to ensure more widespread engagement and avoid sectoral fragmentation causing difficulties during implementation); ${ }^{21}$ joining up currently separate water planning processes and mining and gas development approval processes; ${ }^{22}$ and legislating commitments to create, sustain and fund deeper deliberative engagement across a broader range of interests. ${ }^{23}$ Pursuing such reforms will enhance opportunities for greater community 'buy-in' and produce more innovative, integrated and effective responses to local water problems.

16 Tan, Bowmer and Mackenzie, above n 9; Po-Ling Tan, Kathleen Bowmer and Claudia Baldwin, 'Continued Challenges in the Policy and Legal Framework for Collaborative Water Planning' (2012) 474 Journal of Hydrology 84; NWI $2004 \mathrm{cl} 97$.

17 Sue Jackson et al, 'Meeting Indigenous peoples' Objectives in Environmental Flow Assessments: Case Studies from an Australian Multi-Jurisdictional Water Sharing Initiative' (2015) 522 Journal of Hydrology 141; Tan, Bowmer and Baldwin, above $\mathrm{n} 16$.

18 NWC, above n 5, 27.

19 Bruce Lindsay, 'Public Participation, Litigation and Adjudicative Procedure in Water Resources Management' (2016) 33(4) Environmental and Planning Law Journal 325; National Water Commission, The NWI - Securing Australia's Water Future: 2011 Assessment (NWC 2011).

20 NWC, above n 5, 408-9.

21 Claudia Baldwin and Mark Hamstead, Integrated Water Resource Planning (Earthscan, 2015) 218.

22 NWC, Water for Mining, above n 13, 6; Poh-Ling Tan, David George and Maria Comino, 'Cumulative Risk Management, Coal Seam Gas, Sustainable Water, and Agriculture in Australia' (2015) 31(4) International Journal of Water Resources Development 682.

23 See Cameron Holley and Darren Sinclair, 'Deliberative Participation, Environmental Law and Collaborative Governance: Insights from Surface and Groundwater Studies' (2013) 30(1) Environmental and Planning Law Journal 32; Mark Hamstead, Claudia Baldwin and Vanessa O'Keefe, 'Water Allocation Planning in Australia', Waterlines (6) (NWC, 2008); Baldwin and Hamstead, above $\mathrm{n} 21$. 


\section{B. Embrace regulatory pluralism to address market failures}

A cornerstone of Australia's water reforms has been a cap and trade market-based system. Like market-based approaches in climate, pollution, biodiversity and fisheries contexts, ${ }^{24}$ Australia's water market scheme is underpinned by a belief that environmental degradation occurs because of a failure to properly value environmental resources. ${ }^{25}$ By setting a cap on acceptable resource use levels, assigning rights to extractors and enabling those rights to be traded, governments seek to facilitate rational, selfmaximising individuals to promote 'public interests' by relocating natural resources to those who value them most highly in both the long and the short term. ${ }^{26}$ Over the last 20 years this approach has delivered important benefits, at least in the Murray Darling Basin where significant surface water trading is occurring. Trading has facilitated flexible responses to droughts, ${ }^{27}$ and produced economic benefits for individual farmers and regional communities (albeit selectively and relatively), by providing new sources of income, securities for loans and reinvestment on farms. ${ }^{28}$ Moreover, these benefits appear likely to intensify, as there are encouraging signs that Australia's water market is increasingly functioning at a more optimal and efficient level, as a result of ongoing facilitation of trade and diffusion of information. ${ }^{29}$

Despite these benefits, Australia's water markets confront many ongoing challenges, including limited trading outside of the Murray Darling Basin and perhaps most significantly the lack of universality of environmental impacts in the context of groundwater trades. The use of market trading as an environmental tool works best when there is universality of the environmental impact; however, in the case of discrete groundwater

24 See Cameron Holley and Darren Sinclair 'Governing Water Markets - Achievements, Limitations and the Need for Regulatory Reform' (2016) 33(4) Environmental and Planning Law Journal 301.

25 Ronald Coase, 'The Problem of Social Cost' (1960) 3 Journal of Law and Economics 1; Antonio Roma, 'Energy, Money and Pollution' (2006) 56 Ecological Economics 534.

26 Bradley Karkkainen, Archon Fung and Charles Sabel, 'After Backyard Environmentalism' (2000) 44 American Behavioural Scientist 692, 693; National Water Commission (NWC), Water Markets in Australia: A Short History (NWC, 2011) 8; Holley and Sinclair, above n 24, 302.

27 Sarah Wheeler et al, 'Reviewing the Adoption and Impact of Water Markets in the MurrayDarling Basin, Australia' (2014) 518 Journal of Hydrology 28, 37.

28 NWC, above n 5, 358-59.

29 Sarah Wheeler, Alec Zuo and Neal Hughes, 'The Impact of Water Ownership and Water Market Trade Strategy on Australian Irrigators' Farm Viability' (2014) 129 Agricultural Systems 81; Holley and Sinclair, above n 24, 321. 
aquifers, it is both environmentally undesirable to trade water in or out, and virtually physically impossible. To the extent that such situations prevail, the policy of water trading may be compromised. Indeed, despite making up around 21 per cent by volume of entitlements on issue in Australia, trading of groundwater entitlements is quite limited in most jurisdictions, accounting for around 12 per cent of total entitlement trading and only around 1 per cent of allocation trading (in NSW and Vic). ${ }^{30}$ The limited trading of groundwater means that the consequential economic efficiencies will likely be undermined. ${ }^{31}$ In light of this challenge, other complementary policy approaches are arguably needed to plug the gaps in market operation for groundwater.

As legal pluralist theories suggest, complementary mixes of instruments can often produce better outcomes than a reliance on a single instrument approach. ${ }^{32}$ To address the limitations of the market regarding groundwater, reforms should accordingly focus on utilising a more comprehensive and complementary suite of innovative regulatory approaches, such as prescription standards (e.g. requirements that regulated actors adopt particular technologies or best practice or equivalence provisions), process standards (e.g. regulated entities establish target, auditing and reporting processes particular to their circumstances ${ }^{33}$ and perhaps more credibly the model of Audited Self-Management (ASM). I have argued elsewhere (with Sinclair) that the ASM model, which uses a mix of prescription, process and performance standards (e.g. setting and allocating an allowable water extraction or setting a particular level of pollutant), offers an innovative way to harness the benefits of flexibility (inherent to markets), while re-engaging and building trust with the agricultural community (an important issue given the weaknesses in planning discussed above). ${ }^{34}$ Implementing ASM would involve establishing policy to support six

30 Holley and Sinclair, above n 24, 316-17; National Water Commission, Australian Water Markets: Trends and Drivers 2007-08 to 2012-13 (Australian Government, 2011), 5, 37, www.nwc. gov.au/publications/topic/water-industry/trends-and-drivers-2012-13.

31 GHD, Hamstead Consulting and Vanessa O'Keefe, A Framework for Managing and Developing Groundwater Trading (NWC, 2011) xii; Holley and Sinclair, above n 24, 316-17.

32 Neil Gunningham, Peter Grabosky and Darren Sinclair, Smart Regulation (Oxford University Press, 1998).

33 For further discussion of these and other regulatory approaches, see Neil Gunningham and Cameron Holley, 'Next Generation Environmental Regulation' (2016) 12 Annual Review of Law and Social Science 273; Cameron Holley and Darren Sinclair, 'A New Water Policy Option for Australia? Collaborative Water Governance, Compliance and Enforcement and Audited Self-Management' (2014) 17(2) Australasian Journal of National Resources Law and Policy 189, 195.

34 Holley and Sinclair, above n 24, 322-23. 
core ASM features, namely: enabling water users to form a legal entity or collective capable of managing the ASM program; allocating to the entity a collective water right (in effect, a bubble licence) covering all the ASM participating members; enabling participants to determine individual annual extractions as they see fit (effectively trading within the bubble licence); ensuring members have in place accurate metering that uses telemetry to generate real-time water extraction data; making the extraction data available to all participants (disaggregated to the individual level) and the government regulator (aggregated to the collective level); and putting in place, under the ASM program, appropriate integrity (e.g. auditor) and enforcement mechanisms to ensure compliance, including, if necessary, the capacity to draw on the support of the external government regulator. ${ }^{35}$

\section{Support and implement water regulation}

A core element of Australia's water governance approach is traditional regulation, conducted primarily by state-based regulatory agencies. Effective regulation, compliance and enforcement is vital to the NWI. The entire edifice of the market can be undermined if caps set in collaborative water allocation plans are exceeded due to illegal water extraction; if the various licences, approvals and tradeable water rights (essential to efficient markets) are not adhered to; and if stakeholders lack confidence that there is an equitable sharing of water resources (particularly in periods of drought). ${ }^{36}$ While traditional regulatory arrangements vary between each state and territory, there are reasons to conclude that they remain less than ideal. In part this is because traditional regulation in the agricultural sector has proven complex and lagged other industries, ${ }^{37}$ but also because NWI policy attention has naturally focused on establishing plans, entitlements and markets, rather than their enforcement. In view of these challenges, significant federal government investment was committed to improve state water regulation across Australia. ${ }^{38}$ While NSW and a number of other

35 Holley and Sinclair, above n 24, 323.

36 NSW Office of Water, 'Compliance Policy' (NSW DPI, May 2015), www.water.nsw.gov. au/_data/assets/pdf_file/0005/560192/compliance_policy_2015.pdf; Cameron Holley and Darren Sinclair, 'Compliance and Enforcement of Water Licences in NSW: Limitations in Law, Policy and Institutions' (2013) 15 Australasian Journal of National Resources Law and Policy 149, 151-52.

37 Holley and Sinclair, above n 36.

38 Australian Government Department of Sustainability, Environment, Water, Population and Communities (DSEWPC), National Framework for Compliance and Enforcement Systems for Water Resource Management (Australian Government, 2012). 
states have demonstrated progress in meeting many of the framework's milestones, completion rates across a number of issues (e.g. stakeholder education and monitoring) lag across many states, and federal funding is coming to an end. ${ }^{39}$

More generally, a recent survey on water compliance and enforcement in NSW suggest that water regulation still requires substantial improvement. The findings indicate that only around 49 per cent of respondents (n 604) were confident that water users in their region complied with their licence conditions, with an almost equal amount ( 45 per cent) unsure. ${ }^{40}$ These less than optimal levels of perceived compliance and high levels of uncertainty ${ }^{41}$ are causes for concern, as people who are regulated are less likely to comply with rules where norms of compliance are not widespread in practice. ${ }^{42}$ The risk of non-compliance only appears to be compounded by related results that suggest that very few respondents agreed that compliance officers regularly worked in their region (26 per cent, $\mathrm{n} 533$ ) or that people illegally taking water will be caught (33 per cent, $\mathrm{n} 611){ }^{43}$

To the extent that such problems are reflected across Australia, fixing these challenges and enhancing compliance and enforcement will require increased and continued investment. Such investment will be vital to implementing fundamental regulatory activities, including enhancing public communication of government enforcement; increasing and publicising compliance officer activities (e.g. education and periodic targeting of regions/sectors); leveraging peers and third parties in promoting compliance; and utilising a more responsive regulatory regime that maintains the support of water users.

39 NWC, above n 5, 353.

40 Cameron Holley and Darren Sinclair, Water Extraction in NSW: Stakeholder Views and Experience of Compliance and Enforcement (UNSW CWI, Feb 2015), www.connectedwaters.unsw.edu.au/ sites/all/files/Water-extraction-in-NSW-stakeholder-views-of-compliance-and-enforcement-surveyreport.pdf; Holley and Sinclair, n 24, 315.

41 Moreover, 51 per cent (n 504) wanted more information about compliance and enforcement activities of the regulator. Holley and Sinclair, above n 40 .

42 Ibid.

43 Ibid.; Holley and Sinclair, n 24, 315. 


\section{Rebuild and intensify system-wide monitoring and benchmarking}

Arguably one of the most successful features of the NWI is its system of monitoring and continuous improvement. Significant government funding was committed to monitoring, oversight and continual 'learning by doing' activities, including major investment in the Bureau of Meteorology (which gathered significant national water information); and financial backing for an independent National Water Commission (NWC) - a skills-based body whose tasks included conducting periodic assessments of the reforms and producing a series of related products, research studies, performance indicators and position statements.

Nevertheless, there are a number of shortfalls in the NWI's monitoring and continuous improvement systems. While monitoring of water plan outcomes is still impoverished, ${ }^{44}$ perhaps the biggest shortfall relates to oversight of the NWI system itself. As a tool for improving and progressing the NWI, the NWC assessments were arguably its most important product, helping to facilitate benchmarking of performance. The assessments also shed light on gaps in the agenda, and publicly 'prodded' governments when they were dragging the chain on water reform. ${ }^{45}$ This success is worth noting given that, subsequent to the National Competition Reforms and their incentive arrangements, there has been little funding to encourage state commitment to implementation (other than those tied to specific programs or places like the National Framework for Compliance and Enforcement and the Murray Darling Basin national partnership agreement payments).

Despite the success of the NWC, it was abolished in 2015. This decision was based on the view that progress in implementing the NWI was such that monitoring of national reforms was no longer needed, with statutory functions to be transferred to existing Commonwealth agencies. ${ }^{46}$ With the government left to self-assess progress (albeit alongside ad hoc senate and independent inquiries), the disciplinary drivers that arose from the NWC's public transparency and comparisons are likely to fall away. As the

\footnotetext{
44 National Water Commission (NWC), Monitoring and Evaluation for Adaptive Water Management: Issues Paper (NWC 2013); NWC above n 5, 404.

45 David Rosalky, COAG Review of the National Water Commission (COAG, 2011) iii-iv.

46 P Hannam, 'Parched NSW Seeks Help as National Water Commission Axed', The Sydney Morning Herald, 13 May 2015, www.smh.com.au/environment/parched-nsw-seeks-help-as-nationalwater-commission-axed-20150513-gh0ork.html.
} 
Commission itself noted before being disbanded, there is 'little assurance against backsliding on previous gains ${ }^{47}$ This is particularly worrying given the substantial amount of work still to be completed on water, including recent federal proposals to develop Australia's northern water resources, as well as addressing challenges of coal seam gas, mining, community engagement, regulation and monitoring (noted above).

At a minimum, improving the NWI's commitment to monitoring and improvement goals requires increasing monitoring budgets (e.g. for water plans) and re-embracing an independent oversight body like the NWC. A more fundamental change would extend the NWI monitoring and improvement model so as to mirror the so-called experimentalist learning architecture, ${ }^{48}$ replete with new obligations for localised benchmarking of water plans, greater horizontal diffusion of information between water catchments (facilitated by an oversight body like the NWC), and setting and ratcheting up minimal standards of good performance and process. Doing so would enhance opportunities for sharing more detailed learning and innovation (such as how best to integrate gas and mining in water planning, or manage environmental assets) across contexts, as well as enhancing opportunities for peer-to-peer accountability.

\section{Conclusion}

Continuing to improve Australia's national water law and policy will be central to future water security in an age of climate change. This chapter has surveyed non-urban water governance, identifying successes and several lingering shortfalls, including weak community engagement, gaps in integration, regulation and market trading, and limitations in continuous improvement caused by a dismantling of the NWC. Overcoming these weaknesses will require concerted efforts to continue the evolution and implementation of the NWI goals, such as the efforts canvassed in this chapter.

47 NWC, above n 5, 108.

48 Karkkainen, Fung and Sabel, above n 26. 
This text is taken from New Directions for Law in Australia: Essays in Contemporary Law Reform, edited by Ron Levy, Molly O’Brien, Simon Rice, Pauline Ridge and Margaret Thornton, published 2017 by ANU Press, The Australian National University, Canberra, Australia. 